\title{
Risk of self-Injury by Patients using Video Otoendoscopes Aimed at
}

\section{Home Market}

\author{
Waqas Jamil ${ }^{1 *}$ and Mark Simmons ${ }^{2}$ \\ ${ }^{1}$ Department of ENT, Walsall Manor Hospital, Walsall, UK. \\ ${ }^{2}$ Walsall Manor Hospital, ENT Department, Walsall, UK.
}

*Corresponding Author: Waqas Jamil. ENT department Walsall Manor Hospital, Moat Road, Walsall, WS2 9PS, Walsall, UK.

Received date: December 21, 2021: Accepted date: December 25, 2021: Published date: January 03, 2022

Citation: Waqas Jamil and Mark Simmons. (2022) Risk of self-Injury by Patients using Video Otoendoscopes Aimed at Home Market. J. Clinical Otorhinolaryngology 4(1); DOI: 10.31579/2692-9562/046

Copyright: (c) 2022 Waqas Jamil. This is an open access article distributed under the Creative Commons Attribution License, which permits unrestricted use, distribution, and reproduction in any medium, provided the original work is properly cited

\section{Summary}

We have recently become aware of new small $(2.2 \mathrm{~mm}$ to $5.5 \mathrm{~mm})$ ear wax removal endoscopes (similar to otoendoscopes) aimed at the home market (See Figure 1).

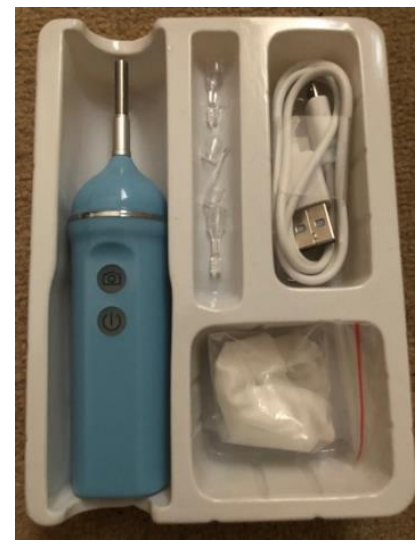

Figure 1: Showing home ear wax removal kit

These are powered by USB attachments and can be viewed on mobile phones or home PCs. They are targeted at the home market for examination of ears, nose, and mouths and even some sellers advocate using their use on pets too. They often come with attachments to allow ear cleaning of wax and removal of foreign bodies etc. These are available on various online seller websites and can cost as little as £11. These have been available for purchase for a few years, but we were not aware of them until we started having some patients attend our emergency ENT clinic recently having damaged their ear canals with them during use. In one case, a child presented with extensive abrasions/laceration of the ear canal after her mother attempted to clean wax from the child's ears.

Similarly, looking at the customer reviews on these online seller websites, other buyers have reported harm using these devices i.e. bleeding from the ear, pushing ear wax further in the ear canal and resulting in hearing loss $[1,2]$.

Having purchased one of these items for home research, we found the otoendoscope unwieldy and it was difficult to gain a good image. Also with mono-ocular vision, there is no depth perception, consequently this may increase the risk of self-injury for new/untrained users. Whilst such devices may well be helpful in the current COVID crisis and could be used for telemedicine to help with distant patient examination during lockdowns $[3,4]$, we would like to highlight the potential dangers of the use of these items by the public.

\section{Financial disclosure}

No financial disclosure.

\section{Conflict of interest}

None to declare.

\section{References}

1. Cuthbert, C. (2021) Review of Masstimo Ear Wax Removal Endoscope, Earwax Remover Tool, Ear Camera,1080P FHD Wireless Ear Otoscope with LED Lights,Ear Scope with Ear Wax Cleaner Tool for iPhone, iPad \& Android Smart Phones. Amazon, 22 February 2021

2. Hannah . (2021)Review of Oxbird Wireless Otoscope Ear Scope Camera Endoscope, 2 Million Pixel High-Definition, The Latest Three-axis Intelligent Image Stabilization, Ear Scope Otoscope with Light,Otoscope iPhone/Android. Amazon.

3. Meng X, Dai Z, Hang C, Wang Y. (2020) Smartphoneenabled wireless otoscope-assisted online telemedicine during the COVID-19 outbreak. Am J Otolaryngol.;41(3):102476.

4. Sclafani AP, Shomorony A, Stewart MG, Grunstein E, Overdevest JB.(2021) Telemedicine lessons learned during the COVID-19 pandemic: The augmented outpatient otolaryngology teleconsultation. Am J Otolaryngol. 
Ready to submit your research? Choose Auctores and benefit from:

This work is licensed under Creative Commons Attribution 4.0 License

To Submit Your Article Click Here: Submit Manuscript

DOI: $10.31579 / 2692-9562 / 046$
i. fast, convenient online submission
ii. rigorous peer review by experienced research in your field
iii. rapid publication on acceptance
iv. authors retain copyrights
v. unique DOI for all articles
vi. immediate, unrestricted online access

At Auctores, research is always in progress.

Learn more auctoresonline.org/journals/journal-of-clinicalotorhinolaryngology 